\title{
TINDAK TUTUR \\ DALAM PERSPEKTIF KAJIAN WACANA
}

\author{
oleh Imam Suyitno \\ Fakultas Sastra Universitas Negeri Malang
}

\begin{abstract}
All members of a society master at least one language and use it in interaction and communication by which they are able to conduct social functions to express their nature as social beings. As social activities, the interaction and communication reflect cultural products expressed in conversational discourse. With regards to the speech act theory, the discourse always occurs in a speech situation, in which a speech event occurs. Speech events consist of speech acts. On the basis of these paradigms, we can conclude that in nature discourse is a set of speech acts so that the speech act theory can be used as an approach to analyzing discourses.
\end{abstract}

Keywords: speech acts, discourse, discourse analysis

\section{A. PENDAhuluan}

Dalam kehidupan bermasyarakat, setiap individu melaksanakan fungsi sosialnya melalui kegiatan berkomunikasi dan berinteraksi. Hal ini sejalan dengan pernayatan Suparno (2000:1) yang menyatakan bahwa komunikasi merupakan hajat hidup semua orang tanpa kecuali sejalan dengan hakikat manusia sebagai makhluk sosial. Dalam berkomunikasi dan berinteraksi, sebagaimana lazimnya, mereka menggunakan bahasa sehingga dalam menjalankan fungsi sosial kemasyarakat mereka melakukan aktivitas berbahasa atau bertutur.

Dalam bertutur, selain terikat oleh kaidah lingual, setiap anggota masyarakat tutur terikat oleh norma sosial dan budaya masyarakatnya. Karena itu, dalam menjalankan aktivitas bertutur, setiap anggota masyarakat tutur harus selalu menghargai dan menghormati norma-norma sosial dan budaya masyarakat, yang kemudian direfleksikan dalam wujud tuturannya. Karena itu, Suparno (2000:2) dalam pernyataan selanjutnya menegaskan bahwa komunikasi merupakan aktivitas sosial yang dilakukan oleh anggota masyarakat tutur dalam berinteraksi dengan sesama sebagai produk budaya. Budaya komunikasi itu dapat dikenali dari wacana komunikasi yang terungkap, yakni satuan kebahasaan yang lebih tinggi dan lebih besar daripada kalimat. Dalam bentuknya yang utuh, wacana tersebut dapat berupa teks, baik berupa teks tulis maupun teks lisan. Hal ini sejalan dengan pernyataan Brown \& Yule (1983:6) yang menyatakan bahwa teks merupakan istilah teknis yang mengacu pada rekaman verbal tindak komunikasi.

Sebagai representasi wacana dan sebagai rekaman verbal tindak komunikasi, teks (baik lisan maupun tulis) memiliki beragam wujud. Teks yang berupa rekaman verbal tindak berdiskusi, berdebat, percakapan, dan tanya-jawab tentu berbeda dengan teks yang berupa rekaman verbal rambu-rambu lalu lintas, surat, makalah, pengumuman, dan iklan. Teks yang merepresentasikan bentuk wacana transaksional tentu berbeda dengan teks yang merepresentasikan bentuk wacana interaksional. Beragam teks tersebut juga memiliki fungsi dan makna yang berbeda jika 
dikaitkan dengan konteks yang berbeda. Suatu tuturan dapat berfungsi permintaan, pertanyaan, atau pun pernyataan dengan makna yang berbeda-beda bergantung pada konteks tuturnya. Kenyataan ini mengundang para analis bahasa, khususnya analis wacana, untuk mengkaji wacana tersebut dari berbagai paradigmanya masing-masing.

Keberagaman wacana sebagaimana dijelaskan dalam uraian di atas merupakan representasi keberagaman peristiwa tutur dalam situasi tutur tertentu. Peristiwa tutur percakapan tentu akan berbeda dengan peristiwa tutur pengumuman, promosi, diskusi, dan sebagainya. Peristiwa tutur tersebut secara konkret terwujud dalam tindak-tindak tutur. Dalam hal ini, dapat dikatakan bahwa keberagaman wacana ini juga mencerminkan keberagam tindak tutur yang membangun kewacanaan tersebut. Itulah sebabnya, dalam mengkaji suatu wacana dapat dimanfaatkan analisis tindak tutur sebagai salah satu pendekatan dalam kajiannya.

\section{B. TINDAKTUTUR}

Tindak tutur merupakan unit dasar komunikasi. Sementara, komunikasi merupakan beragam aktivitas sosial dengan menggunakan bahasa yang terwujud dalam wacana. Dengan demikian, dapat dikatakan bahwa wacana pada hakikatnya juga merupakan serangkaian tindak tutur. Karena itu, untuk memahami wacana dapat dilakukan melalui pemahaman tindak tutur. Dalam kaitannya dengan pembahasan tindak tutur ini, perlu dipahami terlebih dahulu pengertian masyarakat tutur, situasi tutur, peristiwa tutur, dan selanjutnya pembahasan tindak tutur.

Masyarakat tutur didefinisikan sebagai sekelompok masyarakat yang memiliki kaidah untuk mengarahkan dan menafsirkan ujaran, dan kaidah-kaidah untuk menafsirkan sedikitnya satu ragam bahasa (Gumperz dan Hymes, 1972:54-55). Lebih lanjut, Hymes (1972:22-23) menjelaskan bahwa masyarakat tutur merupakan sekelompok masyarakat yang seluruh anggotanya memiliki bersama paling tidak satu ragam ujar dan norma-norma untuk pemakaiannya yang sesuai dengan ragam tersebut. Dalam hal ini, masyarakat tutur boleh jadi sesempit satu jaringan interaksi tertutup, yang seluruh anggotanya menganggap satu sama lainnya berada dalam satu kapasitas yang sama. Namun, pada jangkauan yang lebih luas, masyarakat-masyarakat tutur tertentu akan membentuk masyarakat tutur yang lebih besar dan lebih luas. Karena itu, masyarakat tutur tersebut dapat berwujud masyarakat tutur dalam lingkup terbatas - misalnya masyarakat tutur bahasa prokem - dapat pula mencakup seluruh negara - masyarakat tutur bahasa Indonesia.

Dalam kehidupan sehari-hari, masyarakat tutur selalu berada dalam situasi tutur, yakni situasi sosial tempat terjadinya tutur. Situasi tutur ini merupakan anasir nonlingual atau anasir sosial yang menjadi konteks bertutur dan menjadikan tuturan bermakna. Walaupun situasi tutur menjadi latar tutur, situasi tutur tersebut tidak diatur oleh seperangkat kaidah tunggal (Schiffrin, 1994: 142). Dalam kehidupan nyata, contoh situasi tutur tersebut di antaranya adalah situasi upacara, pertengkaran, makan-makan, percintaan, dan sebagainya (Gumperz dan Hymes, 1972:56). Sebagai latar tutur, situasi tutur ini menentukan pemilihan ragam tutur. Suatu ragam kemungkinan dapat digunakan dalam berbagai situasi, misalnya ragam percakapan, tetapi ragam tertentu hanya tepat digunakan dalam situasi terbatas, misalnya ragam doa, khotbah, atau kebaktian, dan sebagainya (Coulthard, 1979:39).

Di dalam situasi tutur, terdapat peristiwa-peristiwa tutur, yakni aktivitasaktivitas, atau aspek-aspek dari aktivitas yang secara langsung diarahkan oleh kaidah-kaidah dan norma-norma penggunaan bahasa (Gumperz dan Hymes, 1972 dan Schiffrin, 1994). Peristiwa tutur ini merupakan unit komunikasi yang paling besar, yang dalam hal ini seseorang dapat menemukan struktur bahasa. Peristiwa tutur tersebut tidak dibatasi oleh situasi tuturnya sehingga beberap peristiwa dapat terjadi secara simultan dalam situasi tutur yang sama. Contoh peristiwa tutur 
yang demikian ini adalah peristiwa percakapan yang berbeda-beda dalam situasi pesta (Coulthard, 1979).

Peristiwa tutur terlaksana dalam tindak-tindak tutur, yakni unit komunikasi yang paling kecil. Satu peristiwa tutur mungkin terdiri atas satu tindak tutur, sebagai contoh adalah doa atau khotbah. Namun, yang paling sering terjadi adalah satu peristiwa tutur terdiri atas beberapa tindak tutur, misalnya, suatu pesta (situasi tutur), percakapan selama pesta berlangsung (peristiwa tutur), dan gurauan yang ada dalam percakapan (tindak tutur).

Tindak tutur merupakan unit dasar komunikasi, dalam hal ini tindak komunikasi tersebut terdiri atas tindak-tindak tutur (Searle, 1983:21). Di sisi lain dikatakan bahwa wacana merupakan penggunaan bahasa dalam komunikasi. Dalam hal ini, wacana dipandang sebagai tindakan baik secara sintagmatik maupun paradigmatik, baik dari segi struktur maupun sistem. Karena itu, dapat dikatakan bahwa wacana pada dasarnya adalah rangkaian keseluruhan tindak tutur, yang antara tindak tutur yang satu dengan lainnya saling berkaitan sehingga membentuk satu kesatuan yang utuh dan koheren (Schiffrin, 1994). Sejalan dengan pernyataan tersebut, dapat dikemukakan bahwa analisis tindak tutur dapat digunakan sebagai salah satu pendekatan dalam kajian wacana.

Teori tindak tutur pertama kali diperkenalkan oleh John Austin, yang ideidenya lebih lanjut dikembangkan oleh John Searle (lihat Schiffrin, 1994 dan Coulthard, 1979). Austin (1978) adalah orang pertama yang menyatakan bahwa terdapat banyak hal yang dapat dilakukan dengan kata-kata. Ia menyatakan bahwa suatu tuturan bukan sekedar pernyataan atau pertanyaan tentang informasi tertentu, tetapi tuturan tersebut merupakan suatu tindakan. Ketika seseorang menyampaikan ujaran tertentu, sebenarnya ia tidak sekedar menuturkan sesuatu, tetapi juga melakukan sesuatu. Tuturan yang demikian inilah oleh Austin disebut kalimat performatif. Untuk menjelaskan lebih lanjut kalimat performatif ini, berikut ini disajikan contohnya.
(1) Saya bertaruh satujuta bahwa AREMA akan memenangkan pertandingan.

(2) Saya berjanji akan menyelesaikan tugas wacana dengan serius.

(3) Saya mewariskan arloji ini pada adik saya.

Dalam tuturan di atas, penutur tidak hanya mengatakan bertaruh, berjanji, dan mewariskan, tetapi penutur juga melakukan tindakan bertaruh, berjanji, dan mewariskan. Menurut Austin (1978) makna atau nilai kalimat tersebut adalah pada tindakan melakukan pertaruhan, membuat janji, dan menyampaikan warisan. Dalam hal ini, kalimat tersebut tidak bisa dinilai benar atau salah, tetapi dilihat pantas atau tidak pantas. Untuk menilai apakah kalimat tersebut pantas atau tidak, ada beberapa hal yang harus diperhatikan, yakni (a) apakah keadaannya memungkinkan, (b) apakah kalimat tersebut dituturkan oleh orang yang tepat, (c) apakah bahasa dan penuturannya mengikuti prosedur yang benar, dan (d) apakah kalimat tersebut sesuai dengan pikiran, perasaan, dan maksud dikehendaki (bandingkan Schiffrin, 1994:51 dan Coulthard, 1979:12-13).

Selain kalimat performatif, ada juga kalimat yang oleh Austin disebut kalimat konstatif. Kalimat konstatif adalah kalimat yang menyatakan sesuatu, bukan kalimat yang menuntut adanya tindakan. Kalimat tersebut dapat dinilai benar salahnya berdasarkan fakta. Contoh kalimat konstatif adalah Udara di kelas ini dingin sekali. Kalimat tersebut benar jika fakta udara di kelas dingin, dan kalimat tersebut salah jika fakta udara di kelas panas. Yang menjadi pertanyaan sekarang: bagaimanakah cara mengenali bahwa suatu kalimat itu performatif atau konstatif? Apakah ciri penanda bahwa sebuah kalimat itu performatif atau konstatif? Kalimat performatif ditandai oleh (1) subjek kalimatnya orang pertama tunggal, (2) verbanya bentuk aktif, simple, dan present (untuk tuturan bahasa Inggris).

Aturan yang diberikan oleh Austin di atas mengandung kelemahan karena ada juga kalimat yang tidak menuntut adanya tindakan, tetapi di dalamnya mengandung kata verba 
performatif. Sebagai contoh, kalimat Saya setuju dengan usul mereka itu. Dalam menghadapi problema yang demikian ini, Austin menjelaskan bahwa kalimat tersebut sebenarnya merupakan kalimat performatif. Kalimat-kalimat yang demikian ini dapat (a) dikurangi (reducible), (b) diperluas (extenable), (c) dianalisis (analysable), dan (d) direproduksi (reproducible) menjadi kalimat performatif. Berdasarkan hal tersebut, berarti pandangan Austin tentang perbedaan kalimat performatif dengan kalimat konstatif, performatif eksplisit dengan performatif primer tidak dapat dipertahankan karena kedua jenis kalimat tersebut sama-sama melibatkan masalah benar salah, dan kondisi kelayakan dan ketidaklayakan (bandingkan Schiffrin, 1994:53 dan Coulthard, 1979:12-13).

Teori tindak tutur Austin tersebut lebih lanjut dikembangkan oleh Searle dan menempatkannya teori tersebut dalam teori linguistik. Searle juga mengenalkan ide-ide penting tentang tindak tutur yang dapat diterapkan pada wacana. Menurut Searle (1983:21), dalam komunikasi tutur terdapat tindak tutur. Ia berpendapat bahwa komunikasi bahasa bukan sekedar lambang kata atau kalimat, tetapi lebih tepat dikatakan sebagai produk dari lambang, kata, atau kalimat yang berwujud tindak tutur. Secara tegas, dapat dikatakan bahwa tindak tutur adalah produk dari suatu kalimat dalam konteks tertentu dan merupakan satuan dasar dari komunikasi bahasa (Schiffrin, 1994:54). Karena komunikasi bahasa dapat berwujud pernyataan, pertanyaan, dan perintah, tindak tutur dapat pula berwujud pernyataan, pertanyaan, dan perintah.

Tindak tutur dalam ujaran suatu kalimat menentukan makna kalimat tersebut. Namun, makna kalimat itu tidak semata-mata ditentukan oleh tindak tutur tersebut sebagaimana yang berlaku dalam kalimat yang sedang diujarkan itu, tetapi selalu dalam prinsip adanya kemungkinan untuk menyatakan secara tepat apa yang dimaksud oleh penuturnya. Karena itu, dalam setiap tindak tutur, penutur memiliki kemungkinan untuk menuturkan kalimat-kalimat tertentu untuk menyesuaikan ujaran tersebut dengan konteksnya. Dengan demikian, dapat dinyatakan bahwa teori tindak tutur adalah teori yang cenderung mengkaji makna kalimat, dan bukannya teori yang mengkaji struktur kalimat.

Ketika seorang penutur ingin mengemukakan sesuatu kepada orang lain, hal yang ingin disampaikannya itu adalah makna atau maksud kalimat. Untuk menyampaikan makna atau maksud tersebut, penutur harus menuangkannya ke dalam wujud tindak tutur. Tindak tutur yang akan dipilihnya bergantung pada beberapa faktor, antara lain: dengan bahasa apa tuturan tersebut harus disampaikan, siapa mitra tutur yang akan menjadi penerima ujarannya itu, dalam konteks yang bagaimanakah tuturan tersebut disampaikan, dan kemungkinan struktur bahasa yang manakah akan digunakan untuk tuturan tersebut. Dengan demikian, untuk menyampaikan satu maksud perlu dipertimbangkan berbagai kemungkinan tindak tutur sesuai dengan situasi tutur, posisi penutur, struktur yang ada dalam bahasa yang digunakan untuk bertutur, dan mitra tutur.

Dalam tindak tutur tersebut, menurut Austin (dalam Schiffrin, 1994; Coulthard, 1979; dan Levinson, 1986), suatu ujaran memperformansikan beberapa tindak secara simultan, yakni tindak lokusi, tindak ilokusi, dan tindak perlokusi. Tindak lokusi mengaitkan suatu topik dengan suatu keterangan dalam suatu ungkapan, serupa dengan hubungan antara pokok dan predikat atau topik dan penjelasan dalam sintaksis. Karena itu, lokusi suatu tuturan terletak pada makna dasar dan referensi tuturan itu. Tindak lokusi ini oleh Searle (1983) disebut tindak proposisi, yang mengacu pada aktivitas menuturkan kalimat tanpa disertai tanggung jawab penuturnya. Yang diutamakan dalam tindak lokusi ini adalah isi ujaran yang diungkapkan oleh penutur. Tindak ini merupakan dasar bagi tindak tutur lain, lebih-lebih bagi tindak ilokusi (Austin, 1978). Tindak ilokusi merupakan pengucapan suatu pernyataan, tawaran, janji, pertanyaan, dan sebagainya yang berhubungan 
erat dengan bentuk-bentuk bahasa yang mewujudkan suatu ungkapan. Karena itu, lokusi suatu tindak bahasa atau tuturan terletak pada daya yang ditimbulkan oleh pemakaian bentuk bahasa atau tuturan sebagai suatu perintah, pujian, keluhan, ejekan, dan sebagainya. Dalam kaitannya dengan tindak ilokusi ini, Austin (1978:142) mengatakan bahwa tindak menutur sesuatu (of saying) berbeda dengan tindak dalam menuturkan sesuatu (in saying). Tindak menuturkan sesuatu hanya bersifat mengungkapkan informasi tertentu, sedangkan tindak dalam menuturkan sesuatu mengandung tanggung jawab si penutur untuk melaksanakan tindakan tertentu sehubungan dengan isi ujaran. Tindak menuturkan sesuatu ini oleh Austin disebut tindak lokusi, sedangkan tindak dalam menuturkan sesuatu disebut tindak ilokusi. Dalam tindak ilokusi ini, didapatkan daya yang mewajibkan penutur untuk melakukan suatu tindak tertentu sebagaimana yang diujarkan. Tindak perlokusi merupakan hasil atau dampak tuturan yang dikemukakan oleh penutur kepada mitra tutur. Karena itu, perlokusi suatu tindak tutur terletak pada hasil dari apa yang dituturkan penutur kepada mitra tutur.

Ketiga macam tindak tutur tersebut sesungguhnya selalu tecermin dalam bentukbentuk tuturan yang digunakan dalam interaksi karena ketiganya sesungguhnya hanya merupakan cara melihat dan memahami suatu tuturan. Sebuah tuturan selalu memuat lokusi, ilokusi, dan perlokusi. Misalnya, tuturan Rumahmu bersih sekali, (i) memiliki lokusi menyatakan penggambaran keadaan rumah mitra tutur, (ii) memiliki ilokusi pujian atau pun ejekan bergantung keadaan rumah, (iii) memiliki perlokusi gembira jika rumah itu memang bersih atau marah jika keadaan rumahnya ternyata kotor (Soemarmo, 1988:127).

Dalam membahas ketiga macam tindak tutur tersebut, Austin (dalam Coulthard, 1979:18 - 19) mengamati bahwa pembedaan antara tindak ilokusi dan perlokusi sangat mungkin menimbulkan kesulitan. Secara mendasar, tindak ilokusi merupakan tindak bahasa yang diwujudkan dalam ujaran yang berupa kata-kata dalam konteks tertentu, sedangkan tindak perlokusi merupakan tindak nonbahasa yang terwujud sebagai konsekuensi dari tindak lokusi dan ilokusi. Tindak ilokusi, yang dilakukan melalui pengujaran kata-kata tertentu, secara potensial dapat dikendalikan oleh penuturnya, dalam hal ini penutur dapat memilih bentuk-bentuk bahasa yang benar yang sesuai dengan konteksnya. Sementara itu, tindak perlokusi merupakan akibat perubahan yang terjadi dalam benak mitra tutur, apakah ia menjadi khawatir, yakin/percaya diri, atau menolak. Tindakan tersebut terjadi sebagai akibat dari tuturan penutur, tetapi tindakan yang demikian itu bukan akibat langsung dari konvensi yang ada pada tuturan itu. Tidak ada tuturan atau cara yang pasti untuk meyakinkan atau menolak seseorang. Orang dapat saja menolak keinginan orang lain dengan cara melakukan tindak ilokusi membangkitkan keinginan tersebut untuk hal lainnya, tidak harus dengan tindak ilokusi yang secara langsung menolak. Namun, karena ia tahu bahwa ia ditolak, walaupun ujaran tersebut berisi dorongan, tindak perlokusi yang terjadi adalah kekecewaan atau mungkin juga penyesalan. Berdasarkan hal tersebut, Austin membedakan antara objek perlokusi, yakni hasil dari ilokusi yang dimaksudkan oleh penutur, dan akibat perlokusi, yakni hasil dari ilokusi yang tidak dimaksudkan atau hasil sekunder.

Jika dibandingkan dengan tindak lokusi dan perlokusi, tampaknya tindak ilokusi paling banyak mendapat curah perhatian dan pengamatan dari para ahli. Bahkan, tidak jarang bahwa tindak tutur diartikan hanya sebatas tindak ilokusi (Soemarmo, 1988). Sehubungan dengan hal tersebut, berikut ini akan dibahas ragam tindak ilokusi.

\section{RAGAM TINDAK ILOKUSI}

Pemahaman mengenai cara dilakukannya tindak tutur, kaidah-kaidah yang mengarahkannya, dan cara penutur menggunakan bahasa merupakan bagian penting dalam mengkaji tindak tutur. 
Keberadaan tindak tutur ditentukan oleh kaidah yang mengarahkannya. Tindak tutur yang berbeda kemungkinan memiliki maksud sama karena dibentuk oleh kaidah yang sama. Berdasarkan hal tersebut, diperlukan pengelompokan tindak tutur dan tipe-tipe tindak tutur untuk mengnelai hubungan antarkaidah atau pun hubungan antartindakan. Pengelompokan tipe tindak tutur tersebut dapat dilakukan melalui pengategorisasian tindak ilokusi.

Searle (dalam Schiffrin, 1994; Coulthard, 1979; dan Levinson 1983) mengembangkan tindak ilokusi menjadi lima macam, yakni (1) tindak direktif, (2) tindak komisif, (3) tindak representatif, (4) tindak ekspresif, dan (5) tindak deklaratif.

Tindak direktif merupakan tindak tutur yang mendorong mitra tutur melakukan sesuatu. Hal ini menuntut penutur berusaha meminta atau memerintah mitra tutur agar melakukan atau berhenti melakukan sesuatu. Termasuk dalam tindak direktif ini adalah saran, permohonan, perintah, dan permintaan. Contoh tindak direktif ini adalah sebagaimana tuturan berikut.

(1) Saya harap makalah sudah dapat saya terima dua hari sebelumnya.

(2) Dalam penyajian, hindari pembahasan hal-hal yang elementer.

Dalam kedua tuturan di atas, penutur meminta agar mitra tutur melakukan sesuatu. Pada tuturan (1), penutur meminta atau mengharap agar mitra tutur melakukan suatu tindakan, yakni menyerahkan makalah kepada penutur dua hari sebelum makalah tersebut disajikan, dalam hal ini, P1 meminta P2 agar melakukan X. Pada tuturan (2), penutur meminta mitra tutur agar berhenti melakukan sesuatu, yakni menghindari pembahasan hal yang dianggap elementer, dalam hal ini P1 meminta P2 agar tidak melakukan X.

Tindak komisif merupakan tindak tutur yang mendorong penutur melakukan sesuatu. Hal ini menuntut penutur merencanakan berbagai tindakan yang perlu dilaksanakan selanjutnya. Tuturan yang disampaikan oleh penutur berfungsi untuk menjanjikan atau menolak suatu tindakan. Termasuk dalam tindak komisif ini adalah berjanji, bersumpah, bernazar. Contoh tindak komisif tersebut adalah sebagai berikut.

(3) Saya akan membuat acara sama bulan depan.

(4) Jika punya kesulitan katakan saja, saya siap membantu.

Pada tuturan (3), penutur merencanakan tindakan untuk waktu yang akan datang, yakni membuat acara yang serupa dengan acara yang saat itu disaksikan bersamasama dengan mitra tutur, dalam hal ini P1 berjanji pada P2 untuk merencanakan X. emikian juga untuk tuturan (4), penutur merencanakan melakukan sesuatu jika mitra tutur memerlukan bantuan, dalam hal ini P1 merencanakan X jika P2 memerlukan X.

Tindak representatif disebut juga tindak asertif, yakni tindak tutur yang dapat dinilai benar atau salahnya. Tindak representatif ini merupakan tindak tutur yang menjelaskan apa dan bagaimana sesuatu itu sebagaimana adanya. Hal ini menuntut keteguhan dan tanggung jawab penutur atas kebenaran proposisi yang diekspresikannya. Termasuk dalam tindak representatif tersebut adalah tindak tutur menyatakan, menunjuk, mengemukakan, menjelaskan, memaparkan, dan sebagainya. Contoh tuturan yang berupa tindak representatif adalah sebagai berikut.

(5) Pendopo di daerah Dau itu sangat strategis dan sangat memadai untuk digunakan sebagai tempat pertemuan dalam acara-acara santai.

(6) Kebun salak di sekitar rumah walet itu memberikan kenyamanan dan keamanan bagi burung-burung penghuni rumah itu sehingga betah di situ.

Pada tuturan (5) dan (6) di atas, penutur hanya sekedar menyatakan sesuatu tanpa merencanakan tindakan tertentu, juga tidak menuntut mitra tutur agar melakukan sesuatu. Penutur sekedar mengemukakan dan menginformasikan sesuatu sebagaimana adanya, dalam hal ini P1 mengemukakan X pada $\mathrm{P} 2$. 
Tindak ekspresif merupakan tindak tutur yang berkaitan dengan sikap dan perasaan. Tindak tutur tersebut berupa ungkapan kesenangan, kekecewaan, suka, tidak suka, dan sebagainya. Termasuk dalam tindak ekspresif ini adalah tindak meminta maaf, menyesal, berterima kasih, dan memuji. Sebagai contoh tindak ekspresif ini adalah tuturan berikut.

(7) Saya sangat menyesal tidak bisa ikut merasakan sate "cempe" kemarin.

(8) Saya ucapkan terima kasih atas kesempatan yang telah diberikan kepada saya.

Tuturan (7) merupakan sikap penyesalan penutur karena tidak melakukan tindakan sebagaimana yang dilakukan oleh mitra tutur. Dalam hal ini, P1 bersikap X karena tidak dapat melakukan $\mathrm{Y}$ sebagaimana yang dilakukan P2. Tuturan (8) merupakan ungkapan perasaan positif yang berupa ucapan terima kasih atas perlakuan yang telah diberikan oleh mitra tutur yang berupa kesempatan. Dalam hal ini, $\mathrm{P} 1$ memiliki perasaan $\mathrm{X}$ dengan menuturkan $\mathrm{Y}$ atas perlakuan $\mathrm{Z}$ oleh P2.

Tindak deklaratif merupakan tindak tutur yang berfungsi memantapkan atau membenarkan suatu tindakan atau tuturan lain atau tuturan sebelumnya. Tindak tutur ini menghubungkan isi proposisi dengan realitas yang sebenarnya. Termasuk dalam tindak tutur tersebut adalah menyatakan, membaptis, menghukum, memecat, memberi nama, menetapkan, dan sebagainya. Tuturan berikut ini adalah contoh tindak deklaratif.

(9) "Dengan mengucap syukur kepada Tuhan Yang Mahakuasa, kegiatan ini saya nyatakan ditutup."

(10) "Melalui pertimbangan yang cukup matang, akhirnya nama-nama 10 orang berikut ini saya tetapkan sebagai nominator dalam pemilihan calon Srikandi Pariwisata Kota Malang”.

Tuturan (9) merupakan tindak deklaratif menyatakan. Isi proposisi dari tuturan tersebut adalah pernyataan menutup kegiatan dan realitasnya dengan pernyataan tersebut suatu kegiatan berarti ditutup atau selesai. Tuturan (10) merupakan tindak deklaratif menetapkan. Isi proposisi tuturan tersebut adalah saya menetapkan nominator calon Srikandi Pariwisata Kota Malang, realitas yang terjadi dengan penetapan tersebut nama-nama yang ditetapkan menjadi nominator. Dalam hal ini, P1 menghubungkan isi proposisi $\mathrm{Xa}$ tentang realitas $\mathrm{Xa}$ sehingga menjadi $\mathrm{P} 2$ dalam realitas $\mathrm{Xa}$.

Tindak deklarasi tersebut, menurut Searle, merupakan tindak ilokusi khusus. Tindak tersebut hanya dilakukan oleh seseorang yang memiliki kewenangan untuk melakukan tindak tersebut. Untuk menyatakan bahwa kegiatan ditutup, hanya layak jika diucapkan oleh ketua atau yang diberikan kewenangan untuk menutup kegiatan itu. Demikian juga, untuk menetapkan 10 orang nominator, hanya sah jika ditetapkan oleh dewan juri yang berwewenang untuk menilai para peserta tersebut.

Dalam komunikasi sehari-hari, maksud tindak tutur tidak selalu disampaikan dalam wujud tuturan yang lugas, tetapi maksud tersebut disampaikan secara tersembunyi dibalik tuturan itu. Untuk menyampaikan tindak tutur berjanji, verba performatif berjanji tidak selalu secara eksplisit diujarkan. Demikian juga, tindak tutur meminta atau memerintah tidak selalu diwujudkan dalam tuturan yang berupa kalimat imperatif, kemungkinan dapat diwujudkan dalam tuturan yang berupa kalimat tanya.

Sejalan dengan pembahasan tentang maksud tindak tutur dan wujud tutur tersebut, Coulthard (1979:25-26) membedakan tindak tutur langsung dan tindak tutur tidak langsung. Tindak tutur langsung adalah tindak tutur yang perwujudannya disampaikan dalam tuturan secara lugas, yakni kalimat tanya difungsikan untuk melakukan tindak bertanya, kalimat perintah difungsikan untuk melakukan tindak memerintah, meminta, atau pun mengajak, dan kalimat berita difungsikan untuk mengatakan atau memberitakan sesuatu. Sebaliknya, tindak tutur tidak langsung adalah tindak tutur yang disampaikan dalam wujud tutur yang tidak 
secara langsung menunjukkan pernyataan, perintah, atau pertanyaan, misalnya untuk meminta tolong dapat dilakukan dengan menggunakan wujud tutur yang berupa pertanyaan. Tindak tutur tidak langsung tersebut dapat dicontohkan untuk tindak memerintah berikut ini.

- Can you pass the salt? (Tuturan mengenai kemampuan mitra tutur)

- Areyou going to pass the salt? (Tuturan mengenai tindakan yang akan dilakukan mitra tutur)

- I would like (you to pass) the salt? (Tuturan mengenai keinginan penutur)

- Would mind passing the salt? (Tuturan mengenai kemauan mitra tutur)

- I don't think you salted the potatoes. (Tuturan mengenai alasan untuk suatu tindakan)

- Can I ask you to pass the salt? (Tuturan yang melekatkan performatif eksplisit)

Berdasarkan data di atas, dapat dikatakan bahwa dari segi wujudnya tuturan di atas merupakan kalimat tanya dan kalimat pernyataan. Namun, dalam tindak tutur tersebut, melalui pertanyaan atau juga pernyataan, penutur mendorong mitra tutur untuk melakukan tindakan tertentu dapat terlaksana. Dengan demikian, tindak tutur tersebut merupakan tindak permintaan yang termasuk dalam tindak direktif tidak langsung.

Pemahaman maksud tuturan tidak langsung, bagi penutur asli bahasa tersebut, tidak banyak menimbulkan kemacetan atau gangguan komunikasi. Kebanyakan penutur asli telah memiliki presuposisi dan referensi yang sama sehingga dengan menggunakan konteks tutur yang ada mereka mampu memahami implikatur dan mampu menarik inferensi dari maksud tuturan tersebut. Mereka telah memiliki intuisi untuk dapat memahami maksud suatu tuturan tidak langsung. Namun, bagi penutur asing untuk memahami maksud tuturan tersebut, diperlukan pemahaman dan penafsiran urutan ujaran serta kesadaran untuk mengenali akibat yang terjadi pada akhir segmen pembicaraan (lihat Edmondson,
1981:21). Hal ini dapat dijelaskan dengan 2 contoh data percakapan berikut ini. Pada percakapan 1, B dapat memahami maksud tuturan A sebagai ajakan bukan pertanyaan. Namun pada percakapan 2, B tidak memahami maksud A sehingga ajakan tersebut dipahami sebagai pertanyaan. Karena itu, B menyampaikan tuturan sebagai jawaban atas pertanyaan A.

\section{Data Percakapan 1:}

(A dan B teman kantor yang sering bersamasama ke warung untuk makan siang dan minum kopi)

$$
\begin{aligned}
& \text { A :Sudah "ngopi"? } \\
& \text { B : Ayo, diAn-Nuryang agak santai. }
\end{aligned}
$$

\section{Data Percakapan 2:}

(A orang Indonesia dan B orang Jepang, sudah saling mengenal dan sudah beberapa kali bertemu)
A :Mas Tomoko sudah "ngopi"?
B :Ehm ... belum. Bapaksudah "ngopi"?
A :Ayo kita ke warung sebelah.

Untuk memahami maksud tindak tutur, diperlukan pula pemahaman terhadap komponen-komponen yang membangun tindak tutur tersebut. Tuturan yang sama akan memiliki maksud yang berbeda jika berada dalam konteks yang berbeda. Demikian juga sebaliknya, maksud tindak tutur yang sama dapat direalisasikan dalam wujud tuturan yang berbeda. Hal ini dapat dicontohkan berikut ini.

\section{- Belum pulang Dik?}

Tuturan di atas merupakan suatu ajakan jika dituturkan oleh seorang teman di kantor, ketika sudah waktunya pulang, melihat temannya masih terus bekerja. Namun, dalam konteks yang lain, tuturan tersebut memang merupakan suatu pertanyaan jika dituturkan oleh seorang suami kepada istrinya di rumah yang sedang menunggu anaknya yang belum pulang dari sekolah. Karena itu, untuk memahami peran konteks tersebut dalam penafsiran maksud tindak tutur, berikut ini akan dibahas struktur konteks tindak tutur. 


\section{STRUKTUR KONTEKS TINDAK TUTUR}

Yang dimaksud dengan struktur konteks tindak tutur adalah komponenkomponen tutur yang membangun peristiwa tutur dan menjadi penentu fungsi tindak tutur. Menurut Hymes (1974), tindak tutur memiliki beberapa komponen, yang meliputi latar, partisipan, fungsi interaksi, tujuan, kunci, topik, saluran, ragam, dan norma. Suatu ragam dapat terjadi karena tujuan tertentu dalam tempat tertentu dengan partisipan tertentu (Coulthard, 1979).

Suatu peristiwa tutur terjadi pada latar tertentu, yakni pada ruang dan waktu tertentu. Latar tersebut dapat mempengaruhi pilihan ragam tutur. Dalam latar formal, terdapat kecenderungan digunakan ragam formal. Dalam latar informal, cenderung digunakan ragam santai. Pemilihan ragam tutur tersebut juga dipengaruhi oleh partisipan tutur. Penutur kemungkinan akan memilih ragam tutur yang lebih akrab jika bertutur pada teman-temannya yang sebaya, tetapi ia akan memilih ragam yang lebih formal jika ia berbicara dengan mitra tutur yang lebih tua atau mitra tutur yang dihormati.

Semua peristiwa tutur dan tindak tutur memiliki fungsi interaksi, yang kadang-kadang hanya sebagai basa-basi. Hal ini dilakukan untuk mengendalikan dan memelihara hubungan sosial antaranggota masyarakat tutur tersebut. Sebagai contoh, sapaan Mau ke mana? Yang hanya mendapat jawab Ke situ itu lo. Dalam tindak tutur tersebut, sebenarnya hanya sekedar menjalankan fungsi basa-basi, tidak ingin mengetahui urusan yang sebenarnya dari mitra tuturnya.

Kunci komunikasi dalam komponen tindak tutur Hymes (1974) menyelaraskan nada tutur seirama dengan sikap penuturnya. Kunci tersebut tampak dari sikap penutur terhadap mitra tuturnya, pilihan ragam tutur, dan penataan nosi dan fungsi sesuai dengan norma budaya penuturnya. Suatu tindak tutur yang sama, dengan latar dan partisipan tutur yang sama akan berbeda bila ada kunci yang berbeda, yaitu susngguh-sungguh atau main-main. Karena itu, Hymes mengatakan bahwa ujaran yang dituturkan dengan nada kasar, boleh jadi, akan memiliki makna yang berlawanan.

Saluran komunikasi dapat mempengaruhi bentuk wacana, yakni wacana tulis dan wacana lisan. Ragam tutur wacana tulis berbeda dengan ragam tutur wacana lisan (Coulthard, 1979). Ragam tutur wacana tersebut tidak hanya ditentukan oleh saluran yang digunakan dalam bertutur, tetapi juga dipengaruhi oleh isi pesan atau topik yang dituturkannya (Hymes, 1974). Ketika penutur menuturkan masalah sehari-hari, ia kemungkinan lebih mantap menggunakan bahasa daerahnya, tetapi ketika menuturkan masalah-masalah formal akademis, ia lebih lancar jika menggunakan bahasa Indonesia. Berkaitan dengan topik tersebut, Coulthard (1979) menjelaskan bahwa ada beberapa topik yang dapat dituturkan dengan siapa saja, dan sebaliknya, ada topik yang dapat dituturkan dan relevan dengan keadaan tertentu saja kepada orang tertentu, dan atau pada waktu tertentu.

Dalam berkomunikasi, semua anggota masyarakat tutur memiliki seperangkat aturan nonlinguistik yang yang mendasarinya, yang mengarahkan mereka kapan dan bagaimana tindak tutur tersebut dilakukan (Coulthard, 1979). Aturan-aturan tersebut tidak tertulis, tetapi telah disepakati oleh anggota masyarakat tutur. Bila ada yang melanggar, akan terjadi konflik, kejutan, timbul kesan negatif, dan sebagainya. Aturan tersebut juga mengatur dalam hal gilir tutur. Dalam suatu percakapan, partisipan tutur memiliki peran yang berubahubah. Ketika partisipan tutur mendapat gilir tutur, sebagai penutur, ia harus dapat mengontrol tuturannya, menentukan topik tuturannya, dan memberikan gilir tutur mitra tuturnya.

\section{E. FUNGSI PENGGUNAAN ANALISIS TINDAK TUTUR DALAM KAJIAN WACANA}

Butir uraian di atas menjelaskan bahwa tindak tutur merupakan unit dasar komunikasi yang terwujud dalam wacana komunikasi. Dari pernyataan tersebut, dapat dikatakan bahwa wacana pada dasarnya berupa serangkaian 
tindak tutur. Dengan demikian, wacana dapat dikaji melalui analisis tindak tutur. Karena itu, pada bagian ini, disajikan penerapan analisis tindak tutur dalam kajian wacana, yang dalam hal ini, analisis tindak tutur difungsikan sebagai pendekatan dalam analisis wacana.

Teori tindak tutur, sebagaimana telah dibahas sebelumnya, memberikan wawasan penting bahwa bahasa memperformansikan tindak komunikatif. Hal ini sesuai dengan hipotesis yang dikemukakan oleh Searle (1983:21) bahwa tindak tutur merupakan unit dasar komunikasi. Hipotesis tersebut menyarankan bahwa terdapat serangkaian hubungan analitis antara makna tindak tutur dengan maksud penutur, maksud kalimat yang diujarkan, pemahaman mitra tutur, dan kaidah yang mengatur unsur-unsur bahasa.

Pada dasarnya, teori tindak tutur berkenaan dengan apa yang dilakukan orang dengan bahasa, yakni berkaitan dengan fungsi bahasa. Secara khusus, fungsi yang menjadi fokus tindak tutur tersebut adalah maksud komunikasi (daya ilokusi suatu ujaran). Hal ini dapat ditandai, misalnya oleh verba performatif, dan direalisasikan dalam kalimat tunggal (Schiffrin, 1994: 90).

Lebih lanjut, Schiffrin menjelaskan bahwa bahasa dapat digunakan dalam tindak tutur karena para penutur bahasa berbagi kaidah, dalam hal ini mereka memiliki pemahaman yang sama tentang kaidah, yang menciptakan tindak bahasa. Sementara itu, suatu ujaran dianggap berhasil memperformansikan tindak tutur apabila ujaran tersebut memenuhi kondisi tertentu. Kaidah mengacu pada pengetahuan linguistik, misalnya hubungan antara "kala" (tenses) dan waktu peristiwa yang dirujuk, sedangkan kondisi mengacu pada pengetahuan tentang dunia, misalnya keharusan orang melakukan tindakan tertentu. Kaidah dan kondisi tersebut mengarahkan pada penggunaan piranti bahasa tertentu untuk menunjukkan daya ilokusi. Dengan pendekatan tersebut, suatu ujaran atau tuturan dapat disegmentasikan dalam satuansatuan atau tindakan yang memiliki fungsi komunikatif yang dapat diidentifikasi.
Pada uraian sebelumnya telah dikemukakan bahwa satu ujaran boleh jadi memiliki lebih dari satu fungsi, yakni lebih dari satu satuan atau tindakan. Sebagaimana yang dicontohkan oleh Schiffrin (1994: 86), Y'want a piece of candy? Menjalankan tiga tindak tutur: pertanyaan, permintaan, dan tawaran.

Ujaran

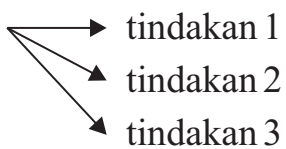

Ketiga tindak tutur tersebut sulit dipisahkan secara tegas karena ketiganya saling berkaitan. Hubungan yang sulit dibedakan secara tegas inilah yang menyebabkan pemahaman "satu bentuk memiliki banyak fungsi". Sehubungan dengan hal tersebut, teori tindak tutur menawarkan suatu pendekatan bagi analisis wacana, khususnya dalam kajian wacana yang memfokuskan makna ujaran sebagai suatu tindakan.

Untuk memahami ujaran virtual yang natural, analis wacana tidak dapat hanya mendasarkan kalimat-kalimat yang terujarkan. Mereka perlu memperhatikan struktur konteks tindak tutur tersebut sehingga dapat memahami maksud kalimat yang diujarkan itu sesuai dengan maksud yang dikehendaki oleh penutur. Dengan memperhatikan struktur konteks tindak tutur dan memahami maksud tindak tutur tersebut, analis wacana dapat memahami praanggapan yang mendasari tuturan itu, referensi yang digunakan oleh penutur, kekoherensian tuturan tersebut, implikatur dari tuturan yang terujarkan. Dengan demikian, mereka dapat menarik inferensi secara benar dari wacana yang dianalisisnya.

Dalam wacana percakapan natural sehari-hari, kekoherensian antarproposisi yang membangun keutuhan wacana itu jarang ditampakkan oleh penanda-penanda formal. Dalam hal ini, yang diutamakan bukan kegramatikalan ujaran yang ditandai oleh kekohesifan kalimat yang diujarkan, tetapi lebih mementingkan keruntutan proposisi yang membangun wacana tersebut. Keruntutan proposisi yang membangun keutuhan wacana itu dapat dilacak melalui konteks tutur dan 
maksud tundak tutur yang terwujud dari peristiwa tutur yang ada.

Contoh:

\section{P1 : Besok ada rapat SPOSIS. Bapak bisa hadir?}

\section{P2 : Saya ada pertemuan dengan rektor.}

Wacana percakapan di atas jika dipahami dari penanda formal, sekilas kedua ujaran tersebut tidak relevan. Dengan kata lain, tidak terdapat keruntutan di antara keduanya. Namun, jika dipahami struktur konteks yang membangun tindak tutur tersebut, jawaban P2 tersebut dapat dikatakan tepat atau relevan. Dalam tuturan tersebut, ujaran yang disampaikan oleh P1 bukan sekedar bertanya, tetapi ujaran P1 tersebut dapat dipahami sebagai permohonan, yakni memohon kehadiran P2 dalam rapat. Karena P2 memahami maksud P1 yang disampaikan melalui tindak tutur tidak langsung, P2 melakukan tindak ilokusi sekunder dengan membuat pernyataan bahwa ia tidak bisa hadir dalam rapat (pernyataan ini bersifat harfiah, tetapi tidak diucapkan). Yang dituturkan oleh P2 adalah tindak ilokusi primer, yakni ujaran yang bersifat tidak harfiah yang diujarkan (Searle dalam Edmondson, 1981:28). Ujaran P2 yang berupa tindak ilokusi primer tersebut dapat dipahami sebagai penolakan.

Berdasarkan hasil analisis di atas, dapat dipahami bahwa kedua ujaran tersebut memiliki koherensi. Ujaran yang dikemukakan oleh P2 tepat dan relevan dengan ujaran yang disampaikan oleh P1. Dalam urutan tindakan tutur, ujaran tersebut dapat disegmentasi dalam urutan tindakan permohonan diikuti penolakan (permohonanàpenolakan). Dalam hal ini, Cook (1989:28) menjelaskan bahwa urutan tindakan yang demikian ini tidak hanya kebetulan, apabila suatu wacana dibentuk oleh dua orang yang melakukan persitindak bersemuka (interacting face to face), urutan tindak tersebut akan terwadahi dalam kata-kata yang diujarkan oleh penutur.

Sebelum sampai pada simpulan tentang fungsi penggunaan analisis tindak tutur dalam kajian wacana, kembali berikut ini disajikan contoh wacana lisan yang dituliskan yang sering kita jumpai dalam kehidupan di masyarakat dekat kampus.

\section{- Ngebutbenjut}

Ditinjau dari ciri formal yang ada dalam kedua data tersebut, ujaran di atas dapat dikelompokkan ke dalam wacana ragam lisan. Sebagai bentuk wacana lisan yang dituliskan, ujaran di atas termasuk peristiwa tutur yang berupa tindak tutur dan terjadi dalam situasi tutur tertentu. Karena itu, untuk menganalisis wacana tersebut, diperlukan pemahaman struktur konteks dan maksud ujaran tersebut.

Jika dikaji dari struktur formalnya, ujaran (1) dan (2) di atas tidak jelas maksudnya, apakah ujaran tersebut merupakan pernyataan, permintaan, atau larangan. Untuk maksud tindak tutur tersebut diperlukan pemahaman struktur konteks tindak tutur yang mendasari ujaran tersebut. Jika diperhatikan dari konteks yang mendasarinya, ujaran di atas terdiri atas sejumlah proposisi yang tidak diujarkan. Karena itu, dalam kajian wacana yang demikian ini, perlu dilakukan pelacakan atau pencarian proposisi-proposisi yang hilang sehingga tersusun sebuah wacana yang utuh. Dari keutuhan wacana tersebut, akan dapat dilihat kekoherensian ujaran tersebut dalam keseluruhan konteks tindak tutur sehingga lebih lanjut dapat ditentukan maksud penutur melakukan tindak tutur yang demikian itu.

Pada ujaran (1), penutur (P1), yakni anggota masyarakat, menganggap bahwa jalan yang ada di wilayahnya itu cukup ramai. Di jalan tersebut, banyak anak yang bermain dan bahkan padat dengan kegiatan anggota masyarakat di sekitar jalan itu. Akan sangat berbahaya bagi anggota masyarakat jika ada orang yang mengendarai kendaraannya dengan kecepatan tinggi di jalan itu karena bisa terjadi tabrakan. Karena itu, P1 memperingatkan mitra tutur (P2), dalam hal ini pengemudi kendaraan, agar tidak mengendarai kendaraannya di jalan itu dalam kecepatan yang tinggi (ngebut) sebab kalau sampai terjadi kecelakaan masyarakat akan marah dan menghajar P2 sampai parah (benjut).

Berdasarkan paparan di atas, dapat dikemukakan bahwa penutur meminta mitra 
tutur untuk tidak mengendarai kendaraannya dengan kecepatan tinggi jika melalui jalan itu. Dalam hal ini, P1 mendorong P2 untuk tidak melakukan X. Berdasarkan kategorisasi tindak tutur yang dikemukakan oleh Searle, tindak yang demikian ini dapat dikatakan sebagai tindak direktif, yang berupa permintaan atau larangan. Walaupun dari perwujudan formal ujaran tersebut berupa kalimat pernyataan, tetapi maksud kalimat tersebut adalah sebagai permintaan atau perintah.

Untuk mengakhiri pembahasan pada butir pembahasan ini, dapat disimpulkan bahwa penggunaan analisis tindak tutur memberikan manfaat bagi kajian wacana. Melalui analisis tindak tutur, analis wacana dapat memahami apa yang dimaksud oleh penutur, kepada siapa tuturan tersebut disampaikan, dan dalam situasi yang bagaimana tuturan tersebut diujarkan. Teori tindak tutur juga menyadarkan analis wacana untuk memahami bahwa penutur tidak hanya melakukan satu hal tertentu dengan katakata, tetapi juga melakukan berbagai hal dengan kata-kata itu.

\section{F. PENUTUP}

Wacana dapat dilihat dari dua sudut pandang yang berbeda, yakni dari segi bentuk dan fungsi. Dari segi bentuk, wacana dipandang sebagai satuan bahasa yang lebih tinggi dan lebih besar daripada kalimat, sedangkan dari segi fungsi, wacana dipandang sebagai penggunaan bahasa dalam komunikasi. Kajian bahasa yang memusatkan perhatiannya pada bentuk dilakukan oleh kaum formalis, sedangkan kajian bahasa yang memfokuskan pada segi fungsi dilakukan oleh kaum fungsionalis.

Dalam wujudnya sebagai penggunaan bahasa dalam komunikasi, wacana berupa serangkaian tindak tutur. Wacana merupakan serangkaian aktivitas tindak yang dilakukan oleh masyarakat tutur dengan menggunakan bahasa. Aktivitas tindak tutur yang dilakukan oleh masyarakat tutur tersebut membangun peristiwa tutur dan terjadi dalam situasi. Peristiwa tutur dalam situasi tutur inilah terungkap dalam sosok wacana komunikasi.
Sebagai unsur pembangun wacana komuniksai, tindak tutur memberikan sumbangan yang bermakna dalam kajian wacana. Analisis tindak tutur dapat dimanfaatkan sebagai salah satu pendekatan dalam mengkaji wacana. Melalui analisis tindak tutur, analisis wacana dapat mengenali koherensi, referensi, implikatur, dan inferensi suatu wacana secara lebih memadai. Dengan memahami situasi tutur, peristiwa tutur, dan tindak-tindak tutur yang membangun suatu wacana, seorang analis wacana dapat memahami makna wacana secara tepat.

\section{DAFTAR PUSTAKA}

Allan, K. 1998. Speech Act Theory - An Overview, dalam Jacob L.Mey dan R.E. Asher (Eds.). 1998. Concise Encyclopedia of Pragmatics. Oxford: Elsevier.

Austin, J.L. 1975. How to Do Things with Words. Cambridge, Massachusetts: Harvard University Press.

Brown, Gillian dan George Yule. 1983. Discourse Anslysis. Cambridge: Cambridge University Press.

Cook, Guy. 1989. Discourse. Oxford: Oxford University Press.

Coulthard, Malcolm. 1979. An Introduction to Discourse Analysis. London: Longman Group Limited.

Edmondson, Willis. 1981. Spoken Discourse: A Model for Analysis. London: Longman Group Limited.

Fairclough, Norman. 1989. Language and Power. London: Longman.

Gumperz, John J. Dan Dell Hymes. 1972. Directions of Sociolinguistics. New York: Holt, Rinehart, and Winston Inc.

Hymes, Dell. 1974. Foundation in Sociolinguistic: An Ethnographic Approach. Philadelphia: PennsylvaniaPress.

Leech, Geoffrey. 1993. Prinsip-prinsip Pragmatik. Terjemahan M.D.D. Oka. 
Jakarta: Penerbit Universitas Indonesia.

Levinson, Stephen C. 1983. Pragmatics. Cambridge: Cambridge University Press.

Marmo, Soemarmo. 1988. Pragmatik dan Perkembangan Mutakhirnya, dalam Soenjono Dardjowidjojo (ed.). 1988. PELLBA I. Jakarta: Lembaga Bahasa Atmajaya.

Schiffrin, Deborah. 1994. Approaches to Discourse. Oxford, UK, Cambridge: Blackwell.
Searle, John R. 1983. Speech Acts: An Essay in The Philosophy of Language. Cambridge: Cambridge University Press.

Stubbs, Michael. 1983. Discourse Analysis: The Sociolinguistic Analysis of Natural Language. Chicago: The University of Chocago Press.

Suparno. 2000. Budaya Komunikasi yang Terungkap dalam Wacana Bahasa Indonesia. Malang: Universitas Negeri Malang. 